\title{
ASSESSING THE INTERGENERATIONAL VALUE TRANSFERS: A LONG-TERM APPROACH CONSIDERING POPULATION AGEING IN THE CZECH REPUBLIC
}

\author{
[Mezigenerační přesun prostředků: dlouhodobý př́stup pro Českou republiku \\ zahrnující stárnutí populace]
}

\author{
Richard Šmilňák ${ }^{1}$ \\ ${ }^{1}$ Moravian Business College Olomouc, tř. Kosmonautů 1288/1, 77900 Olomouc \\ University of Economics, Prague, Nám W. Churchilla 1938/4, 13067 Praha 3 - Žižkov \\ Email: richard.smilnak@mvso.cz.
}

\begin{abstract}
With the ongoing reversal of the population pyramid in the foreground, this paper designs a framework for assessing the intergenerational redistribution due to collective pension, healthcare, and education system funding in the Czech Republic. Employing the generational accounting method for locking the fiscal policy in the base year and deriving individual lifetime net tax payments, overall generational contributions are calculated. This work sheds light on who benefits from and who loses out in the 2015 calibration of the system. The losses are expected for those currently young or yet unborn. The increasing aged dependency ratio puts pressure on the productive population as well as on public finance which results in considerable value transfers from young generations to their predecessors. Such scheme levies - through tax implications of dependency - a high burden of contribution on the population which will be productive especially around the time forty years from now.
\end{abstract}

Keywords: generational accounting, public finance, retirement pensions, value transfers.

JEL classification: H55, H51, H6, J11

Received: 1.10.2020; Reviewed: 2.11.2020; 11.1.2021; Accepted: 27.1.2021

\section{Introduction}

The motivation for this work stems from rising concerns of unfavourable value transfers from those being young to old citizens in 2040 and beyond (peaking around 2060) under the current calibration of the collective PAYG system of pensions, healthcare, and education. The net tax payment contributions assigned to these areas will have to be not only maintained over time, but their overall value needs to increase as a result of rising budgetary needs during the country's demographic transition. Hence, this paper looks into the issue of less taxpayers tending to greater expenses and deals with the following question:

Is the current system - effective through public budgeting - creating a generational divide through a value transfer that leaves less value to future contributors?

The current configuration of Czech public finance remains unsustainable (OECD 2020; Czech Fiscal Council 2020) and whether changed or not, the effects will be felt differently by generations born in varying years.

The aim of this paper, after delineating the net tax payment of a lifetime, is to examine those contributions intergenerationally and to answer the aforementioned question. The following section presents motivation for this paper through presenting an argument of why the budgeting process is so blatantly short-sighted and why it should not be (1). In parts 2 and 3 the mechanism and means of fulfilling the aim are presented while section 4 constructs an overview of the lifelong net tax payments represented by a single economic actor living entirely within the 2015 setting of the system. This actor is then multiplied and fine-tuned to form entire generations 
reflecting the demographic prospects projected for the Czech economy. By doing this, section 5 offers insight into the size and scope of the value transfers needed for sustaining the current system which was crafted in a world where population (and thus the tax base) was on the rise, life was shorter and young people outnumbered their ancestors. Such scenario, however, no longer reflects reality as economies find themselves in a state of a population pyramid reversal, with the Czech economy serving as a prime example.

\section{How far do we currently see when drafting a budget?}

The current budgetary planning process in the Czech Republic is being influenced by the law for fiscal accountability (Law no. 23/2017) which incorporates the Council directive of the European Commission (2011) which states that a single-year perspective of the annual budget serves as a poor base for policymaking. It further demands that a Member State should prepare and adapt a multiannual budgetary perspective. This medium-term budgetary framework is further defined as containing "projections of each major expenditure and revenue item for the budget year and beyond, based on unchanged policies." (EC 2011, article 21). The aforementioned national law which governs the requisites of fiscal prudence puts forth - in its introductory provision - that the state should pursue effort to reaching a healthy and a sustainable level of public finance, considering mainly the support of economy, society, unemployment, and intergenerational cohesion. ${ }^{1}$ This section of the law further implies that such level of public debt which does not impair the long-term sustainability of public finance should be maintained.

The law also establishes the debt-to-GDP ratio to be the determining measure for the level of public debt ${ }^{2}$ while imposing the fiscal strategy to be developed for a timeframe not shorter than 3 years. ${ }^{3}$ This is likely the result of the vaguely worded definition of the medium-term budgetary objectives (MTOs) that are a part of the stability and growth pact. EC (2020) in it demands its Member States to be reaching or endeavour reaching their MTOs which are to be updated every 3 years or more frequently. This effectively means there is no medium-term budgetary plan if a country administration wishes to update theirs frequently claiming it is necessary due to structural reforms. Furthermore, there is no notion of long-term planning in either document (multinational or national).

Such proceedings set the timeframe of the documents - including the budget proposal published by the Ministry of Finance of the Czech Republic to be framed accordingly, hence gripping onto the 3 -year time horizon and barely making it beyond the $y+2$ paradigm in its predictions. As for the (very) long-term projections, there is an institution in operation. The Czech Fiscal Council functions as a newly (2017) established bureau which provides the government with long-term projections over a 50-year horizon. Its role embedded in law however is to submit its yearly findings and projections of the fiscal actions' impact on public finance sustainability to the Chamber of Deputies. ${ }^{4}$ Those help inform the public debate but have thus far had little documented impact on actual budgeting. Early in 2020 the argument of the Council against the loosening of the rules for fiscal prudence during the beginnings of the pandemic-induced economic downturn of 2020 ended up widely dismissed by the Chamber which waged the final decision ${ }^{5}$, although it gained support in the Senate (SCR 2020) ${ }^{6}$. The

\footnotetext{
1 § 2, law no. $23 / 2017$

2 art. $1, \S 13$, law no. $23 / 2017$

3 art. $1, \S 9$, law no. $23 / 2017$

${ }^{4}$ art. 2 d, $§ 21$, law no. $23 / 2017$

${ }^{5}$ Chamber of Deputies proceedings $812 / 3$ (sněmovní tisk)

${ }^{6}$ also in Chamber of Deputies proceedings 812/4
} 
paper which follows argues that this is however no time to be fiscally short-sighted and delineates a framework for assessing the effects of intergenerational redistribution due to considerable value transfers through each generation's lifelong contribution and benefitreceiving to and from the tax system. A country's fiscal effort has the power to shift well-being in time and it is the aim of this paper to depict who gains and who loses prosperity given the current setting in order to support carrying out the much needed future changes in a better informed way. To put matters into perspective, Figure 1 illustrates the reason why the budgeting process ought to adapt a longer range.

Figure 1: Demographic projection for chosen age groups without migration

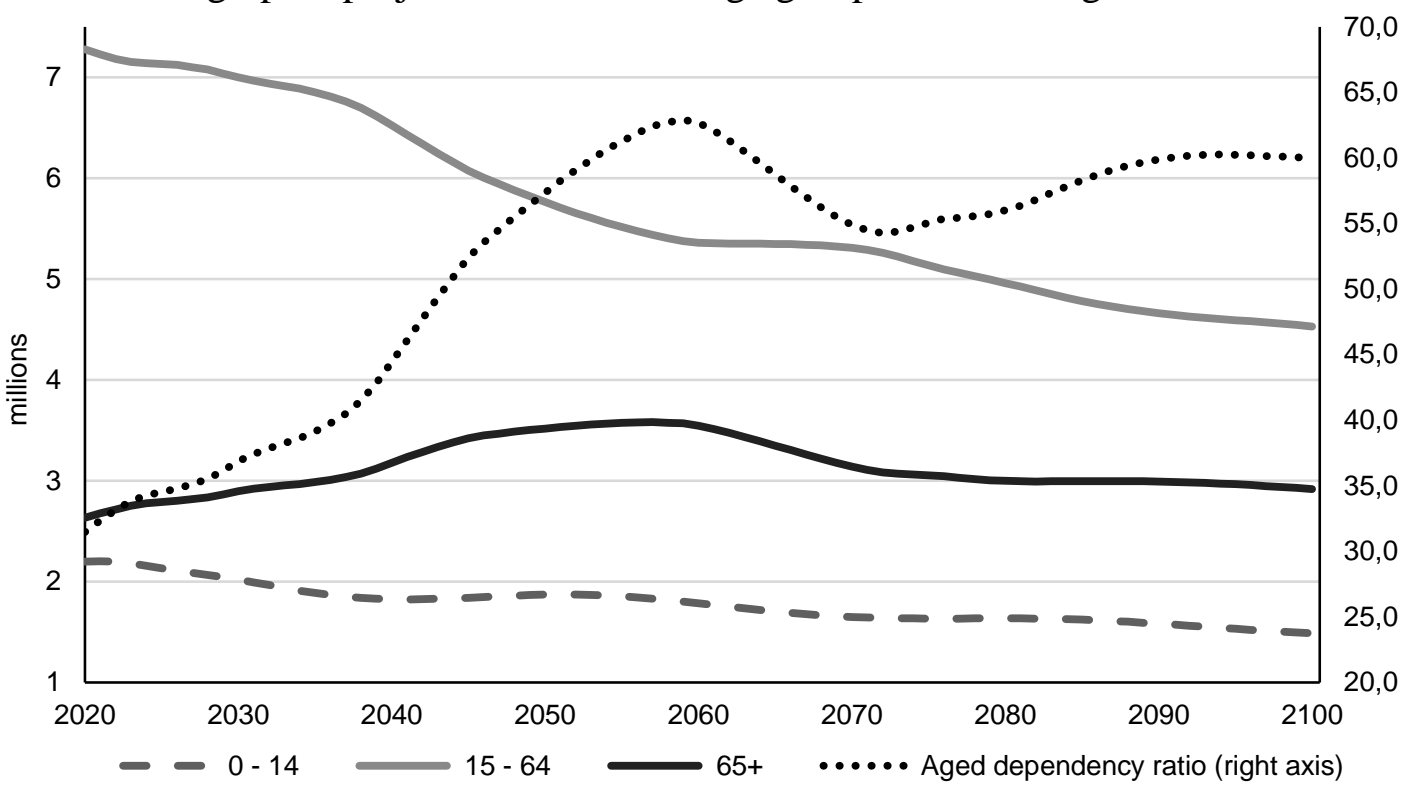

Source: CSO data, own calculations

While the ratio of working age population to retirees stands above 3 in 2020, it is expected to drop to its lowest projected value of 1,58 in 2059 without rebounding too much, hitting 1,7 at the close of the century. The aged dependency ratio underlines this trend as it highlights the pressure put on those aged 15-64 as time goes and the number of people falling into the three age groups fluctuates greatly.

\section{Review of literature}

Intergenerational equity rests at the core of the so-called golden rule of public finance as seen in Robinson (1998). This is also true for the national law governing the accountability for budgetary prudence (Law no. 23/2017). Musgrave (1988) also regards the issue of current generations transferring wealth from their successors to themselves through shifting the tax burden. Alas, as we have learned, paradoxically, the institutions acting - through fiscal effort towards reaching the goal of intergenerational fairness are designed to consider only the short or medium-term impacts of their decision making. The literature offers a modest number of approaches for evaluating long-term intergenerational economic equity. The index of intergenerational equity-2016 published by Gagné et al. (2016) which compares regions concerning 30 social, economic and environmental indicators during past time, spans as lengthy as corresponding data availability allows (starting in 1976 at the oldest). This is done without offering future outlook but with the potential of doing so. Another example is represented by the Sustainable development goals as proposed by the U. N. (2016) which are a call for action on a global scale, calling for fiscal policy to adopt an approach directing its outcomes towards greater equality but focusing on a plethora of issues and offering a much greater scope lacking 
specific measures. Another approach being the Generational accounting which has its roots in the work of economy's towering figures, Buchanan (1958) and Modigliani (1961), who foresaw and discussed the issues raised by public debt enlargement, having the ability to hamper the consumption possibilities of future generations at the benefit of those currently enjoying a bold fiscal move in their favour. The term itself has been nevertheless coined by Auerbach, Gokhale and Kotlikoff (1991) as a method of long-term fiscal planning and analysis. This framework offers forecasting methodology to address the sustainability of public finance as well as the intergenerational value transfer balance and is chosen as an anchoring method for this paper.

\section{Research Methodology}

In order to be able to compare the value a chosen generation gives and receives, the total net tax payment by a member of a chosen generation has to be derived. It is found through an equation provided in Bonin and Patxot (2004):

$$
G A_{k}=\sum_{i=t}^{k+D} \mathrm{~T}_{i, i-k} S_{i, i-k}
$$

for $k \leq t$ where $G A_{k}$ is the currently living generation, $S_{i, j}$ is the probability in period $i$ that a member of the generation aged $j$ survives until the following period. The value of net taxes paid in period $i$ by an individual aged $j$ is quantified by $\mathrm{T}_{i, j}$. Lastly, D stands for the maximum possible lifespan and $t$ is the chosen base year. The expression to summon the accounts of a future generation denoted as $G A_{k}^{f}$ whose members were born in $k>t$ requires a slight adjustment:

$$
G A_{k}^{f}=\sum_{i=k}^{k+D} \mathrm{~T}_{i, i-k} S_{i, i-k}
$$

The original paper discounts the payments by a rate of interest to find their present value. What follows is an analysis where all payments are valued in $2015 \mathrm{CZK}$. The interest rate component is therefore dropped. A generation is defined as everyone born in the same year i.e. there is a single generation for every year except for what Figure 2 shows as the only available healthcare expenditure data groups the generations in 5-year spans. By defining a generation as such, extended work with the data will be smoother and there will be no dispute on how to define a generation when computing and interpreting the results. Such definition aims at easing the hardship brought to a discussion by grouping people into wider generations labelling them with unappealing names. A timeframe between 2020 and 2100 is considered throughout the paper.

In order to obtain cyclically non-biased results, data for tax payments for the year 2015 are chosen. This year is evidenced by the Ministry of Finance (2020) to having an output gap equal to zero. Its choice as the base year will hence help eliminate the end point bias of the projection stemming from it being sensitive to the business cycle as described by Bonin, Patxot and Souto (2014).

\section{Data}

As for the very long-term population forecast, data retrieved from the Czech Statistical Office are employed. For the prediction, the Demographic projection for $2018-2100$ is used while for the past data on how many people are there in a generation, the most recent release is considered (CSO 2018; CSO 2020a). The chosen projection does not factor in the expected migration flows and focuses on nationals only. 
To grasp the tax and transfer payments, data obtained from the Ministry of Finance (2017) are used. The monetary values in this section (4) are in 2015 prices in billion CZK, if not stated otherwise. The revenue side of the budget totalled to 1234,5 out of which 1001,2 amounted in tax revenues. The taxes can be divided between those paid by the economically active population and those paid generally by people on average.

The economically active branch is determined as a cohort of people aged 15-65 while the other categories are set as 0-14 for the young and $65+$ for those eligible for retirement pensions. The amount paid in taxes by those economically active (EA) for 2015 was 607,2 comprising of all direct taxes and the compulsory social and healthcare insurance. The amount paid in taxes by the general population was 394 with its dominant component of indirect taxes, representing 379,6 of the overall. This includes the VAT, various property taxes, the payments for waste management services or even lottery fees.

On the expenditure side, of the total 1297,3 spent, 520,5 amounted in direct social policy related transfers to population (with 395,2 in pensions). A distinction between transfers that sprung economic activity benefitting the general population in the form of activity of firms initiated by government spending, public goods offered by the government or direct payments to population is put in $(595,5)$ - this excludes a part of the non-investment transfers of the budget.

In the corresponding year, national accounts reported by CSO (2020b) evidence 5435384 economically active out of which 5167112 were working with a total population of 10553 800. This is the notion of monetary values no longer being in billion, switching to single units from here on. This makes the 2015 yearly tax paid by an individual generally to be 37 389,4 while the amount paid by those economically active and employed is calculated to be 117551,2 on top of it. Average yearly transfers received by an individual stood generally at 56425,2 with a 11872,5 social component on top of it while the average yearly retirement pension payment of 135792 per pensioner was reported by ČSSZ (2020).

The reason for using ČSSZ data instead of the state budget pension expenditure is that the yearly individual pension payment would be overstated by taking into account those retiring before 65 and spreading the other types of pensions (orphan's, disability etc.) evenly over the studied 65+ cohort.

Data for healthcare expenditures are retrieved from CSO (2017). The set offers an overview of healthcare expenditures by age groups identified as generations of five years each. This is divided by the number of people in each corresponding five-year generation to arrive at individual measures. As for education payments, data taken from OECD (2018) are considered. Those are converted to CZK using the exchange rate for 2015 reported by the same institution.

\section{Results}

Delineating the lifelong cycle of net tax payments, the data for healthcare and education expenditures mark the first years of an individual's life as well as general taxes such as the VAT. By the age of 15 the EA taxes start influencing the calculation for the model agent of 2015 and while these payments are stopped at age 65, the general taxation prevails.

The healthcare expenses of a lifetime are depicted in Figure 2, reflecting the expenditures of caring for the new-borns and then a considerable drop until age 20 starting from which an individual's need for care keeps rising. This causes the costs to keep rising for the reminder of 
life (right axis). On the left axis a total expenditure per a 5-year cohort of patients is shown and if one was to combine only the information from Figure 1 and Figure 2, the picture starts to be very clear.

Figure 2: Healthcare expenses in 2015

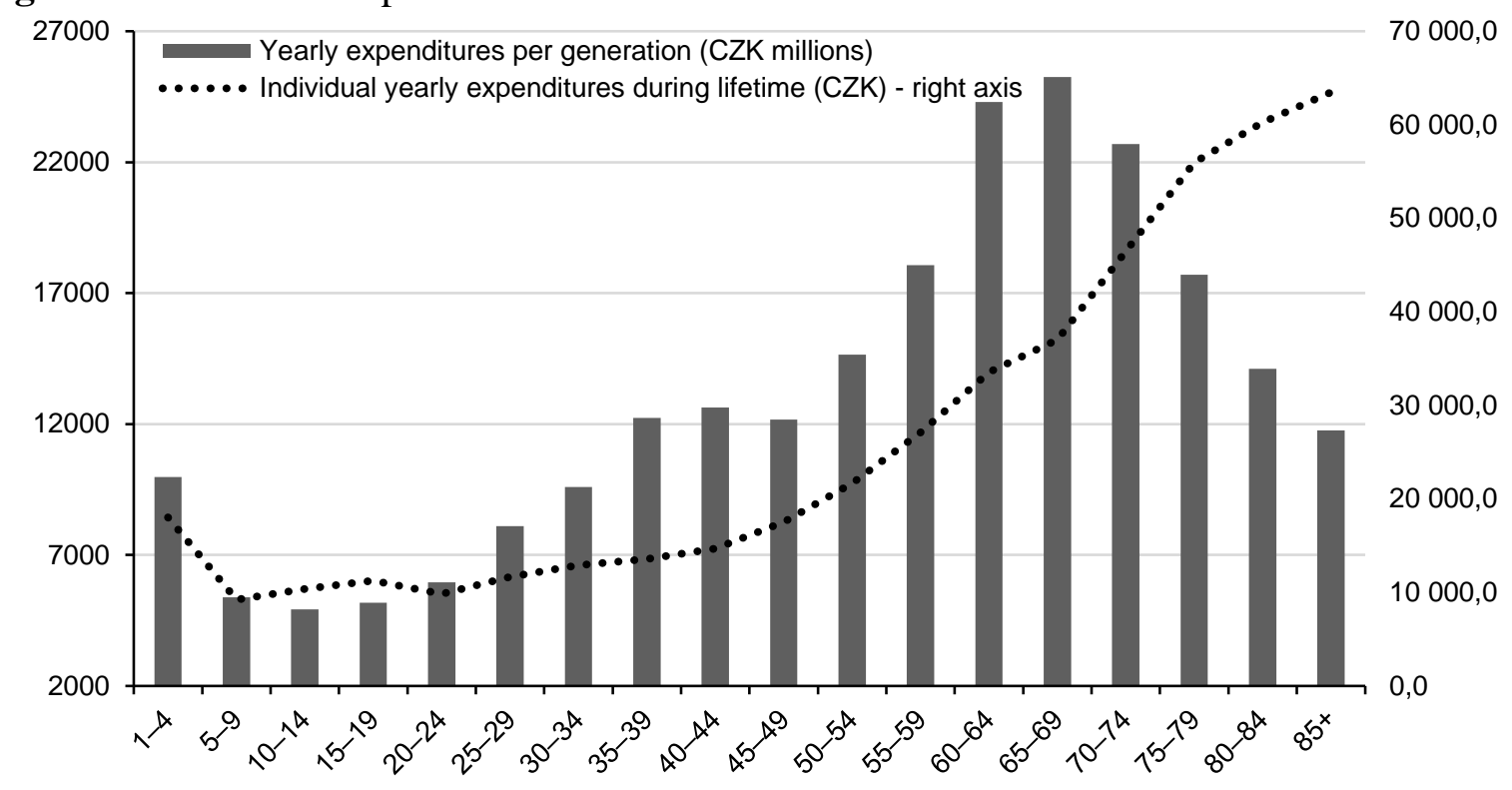

Source: CSO data, own calculations

The Czech Fiscal Council (2020) expects the overall healthcare expenditures to rise by 1 percentage point of GDP between 2020 and 2060 while the retirement pensions are expected to add an extra 4,5 p.p. of GDP burden on public finance in a respective timeframe. Education is projected to add 1,5 p.p. due to rising wages and the need to extend the capacity for tertiary education.

The CZK costs for education in 2015 are listed below and the model agent is seen as an individual spending entire life within the 2015 calibration of the system, attending all education levels including the five-year tertiary enrolment:

128085 primary - 32021 per year for four years 208499 secondary - 23166 per year for nine years 267905 tertiary; 156571 tertiary without R\&D - 35373 per year for five years (average for overall tertiary)

Collating these measures, the results are presented in Figure 3 which combines the types of transfers, taxes and specific benefits described above and provides a visualization of the cycle of lifelong net tax payments which begins with amounting a negative tax during the years until age 28 after which a model individual pays off the education and healthcare expenses accumulated in the early years. Then the agent is "profitable" to the government budget until 75 when things flip again due to accumulated retirement pension payments and steeply rising healthcare costs. After having been a recipient of the retirement pension since the age of 65 , the tax payments accumulated during lifetime are erased and from here on the individual represents a net fiscal burden. The life expectancy was expected at 75,7 for males and 81,6 for females in 2015. This would mean 78,65 years on average which would put an individual with such lifespan to represent a 673012 net fiscal expenditure. 
Figure 3: Trajectory of tax payments of an individual in the base year (CZK)

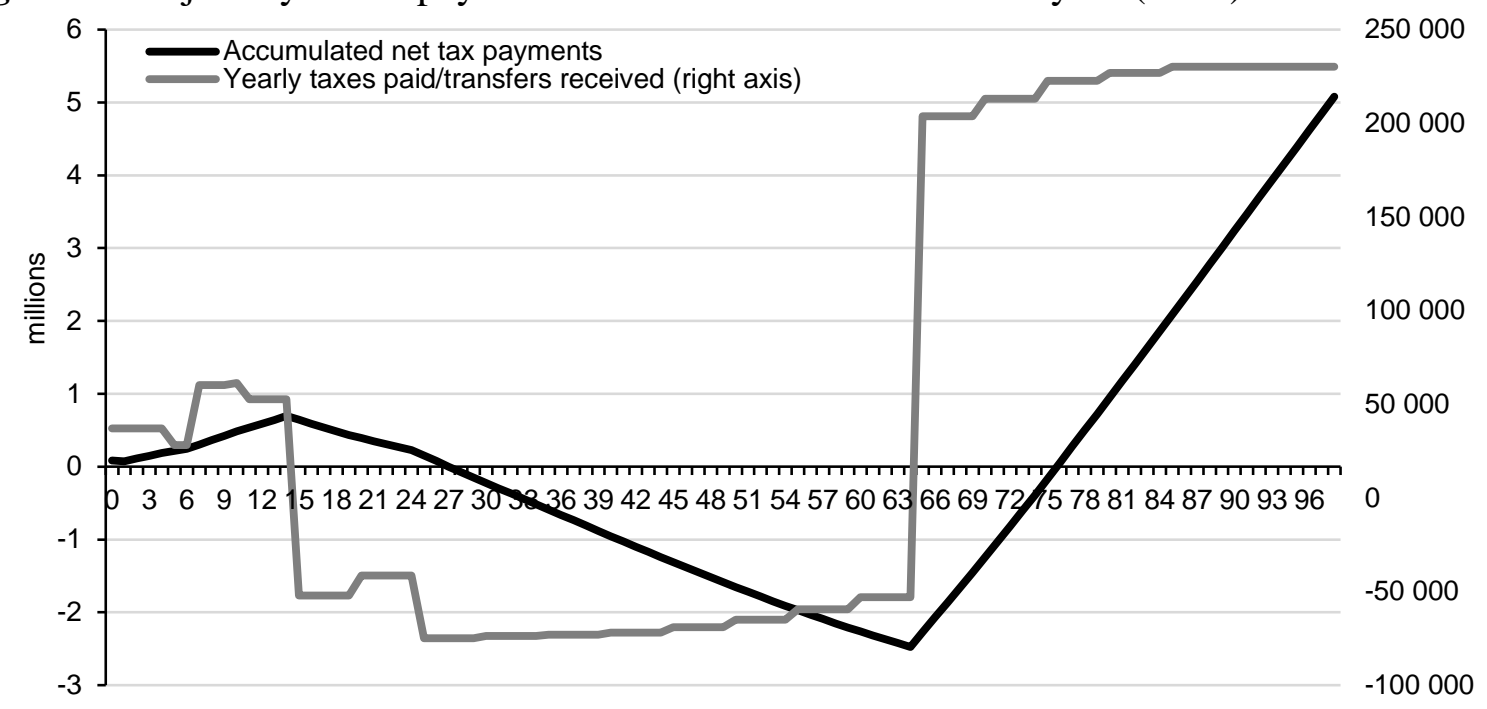

Source: CSO; OECD; ČSSZ data, own calculations

The individual trajectory is seen (from the taxpayer's point of view) in Figure 3 where accumulated tax payments are set beside the yearly net taxes paid by an individual. The negatively sloped section of the accumulated measure gets steeper after an individual finishes school by the age of 25 and begins contributing significantly until around 55 where the slope starts to flatten due to increasing healthcare costs. The extent to which an individual becomes a net loss for the state in this scenario depends on the years lived beyond 76. Life expectancy i.e. the probability of survival until the next period is crucial in determining the final sum but on average, people have been gaining two years of lifetime in each decade for the past two to three decades ${ }^{7}$ in Czechia, extending the taxpayer life cycle and posing a challenge for the expenditure side of the budget.

The main results are shown in Figure 4 after combining individual agents and calculating the generational accounts.

Figure 4: Net tax payments for a corresponding generation during 80 years, starting in 2020

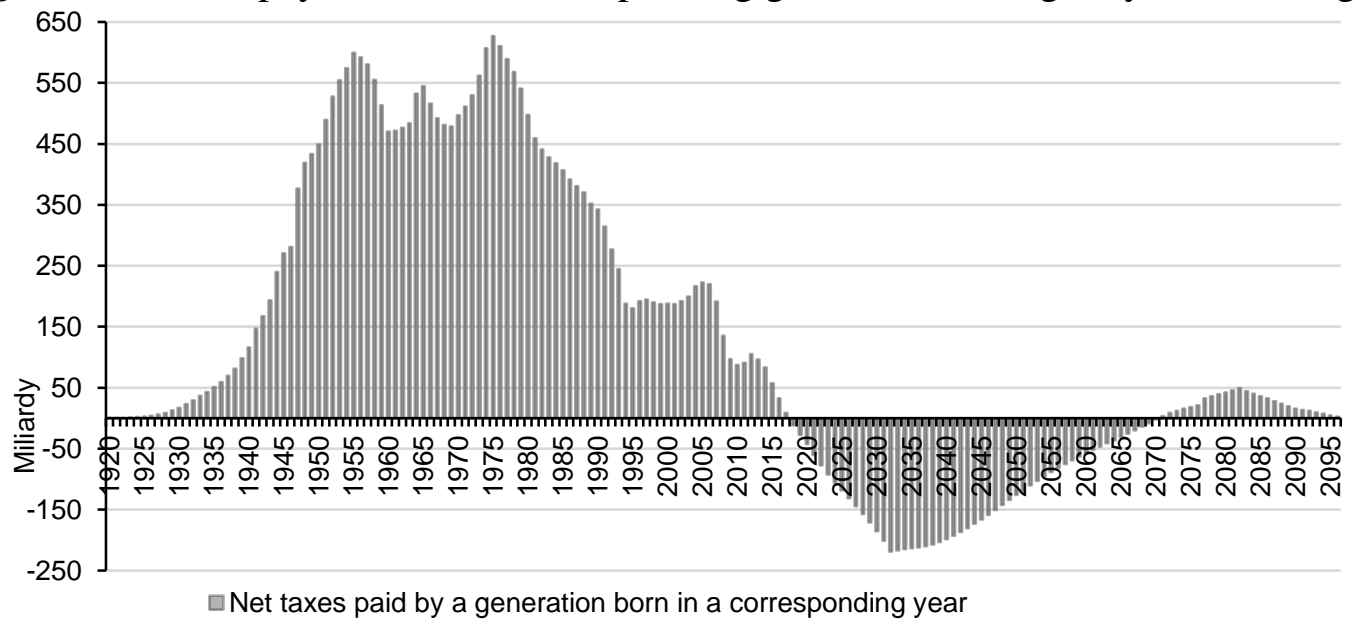

Source: CSO; OECD data, own calculations

\footnotetext{
${ }^{7}$ Fun fact: that means 5 hours per day for 20-30 years that we get to live at the end of life
} 
By following the procedure described on the previous pages, an overview of generational net tax payments is presented. Everyone retires at 65 in the model. The analysis follows the framework of the model agent of 2015 where a positive net tax payment means a net transfer to that generation from the public budget (e.g. the generations of 1920 - 2017). The tertiary schooling expenses were adjusted according to predictions for tertiary enrolment as a portion of total population conducted by Fiala and Langhamrová (2012). It should be again noted that the demographic projection without migration is used and therefore the disproportionality of payments between generations is inflated with less and less young people entering workforce after 2020 as further documented in Jílková and Ř́íhová (2018). This issue is further discussed in the following section. Diminishing number of newcomers entering the workforce is due to the dropping number of new-borns as seen already in Figure 1. Rising probability of living longer also plays a role. The extension of years spent in good health and corresponding implications for healthcare expenditures are not being considered. As the age dependency ratio rises with the strong generations of 1950-1960 being entitled to retirement pension since the beginning of the studied timeframe and the other numerous generations of 1970-1980 starting to retire a decade later, the pressure put on those economically active between 2040 and 2070 intensifies. The generations of 2000-2040 will have to bear the acutely rising expenditures as the baton is passed to them with the need to support the elders who will be for the first time in the welfare state public policy era proportionately so strong in numbers.

The first generation whose full contributions into the system are taken into account is the generation of 2005 and while the previous contributions of those older generations are not factored in (all contributions start in 2020) it is safe to say that there is close to 0 CZK in the system in the beginning as this is the character of the PAYG system. Every generation lives (and dies) simultaneously within the 2015 calibration. As the monetary values are in 2015 money, it allows for the comparison of the value transfer between generations. Those of 20002040, pressured the most, will have to support the - fiscally speaking - heavyweight generations retiring after 2025 and beyond, with the financial hardship culminating around 2060. This documents the value disbalance embedded in the current system designed for the era of population growth. This matter is of a character which requires close attention and serious action. Seen in Figure 4 is the scale of those transfers where e.g. the most populous pensioner cohort of 1975 does get covered by only a third of the expenditures needed to tend to the expenses connected with its longevity and headcount by its best-contributing counterpart found in the generation of 2032 .

\section{Conclusion}

There are ways for the state to transfer value and welfare in time. This work is dedicated to studying the part of this mechanism in which those supporting the welfare of their predecessors would have to put in individually considerably larger payments than those who were there before them and either put the policy in place or chose to leave it unchanged. This paper documents that there is a bug stemming from the current calibration designed in the past and encountering the state of affairs experienced currently which creates disproportionate value transfers from those very young now or born in the next two decades to those retiring in several years from now and until the midpoint of the century. The introductory question is therefore given a positive answer as there is an alarming intergenerational disproportion between what those currently young or unborn are expected to sacrifice to keep a sound welfare level for their ancestors as they simply can't satisfy their old-age related needs without tax rate hikes or extensive public indebtedness. 
The results are applicable for issuing policy recommendations during the budgetary planning process as well as for steering the fiscal efforts towards sustainability while keeping intergenerational equity in mind. Adequate taxation, retirement and migration policies could be based on future research supported by this work. The aim of this paper was fulfilled through conducting the study of tax contributions by respective generations and presenting the opportunity of comparing them side by side. This serves as a call for long run budgetary planning as the mechanism currently effective prevents seeing the issues hereby presented, blinded by considering only a $y+2$ horizon.

It is fair to note that the conceivable future migration flows are not considered. These were generally positive and around 30000 individuals yearly in the past 5 years, although varying greatly in the last two decades. If the trend seen since 1989 prevails and the country attracts and absorbs additional 500000 foreigners (they would also have to belong to younger generations) in the next 25 to 30 years, the effect of the initial national population dying out due to low fertility rates will be offset by newcomers considerably. Those immigrants could ease the fiscal burden which in this paper is only up to the natives to bear.

This paper also gathers evidence which points towards a statement that doing nothing in this sense could be seen as unlawful behavior of the policymakers as promoting intergenerational cohesion should be a benchmark for their efforts according to the national law. Every year of extended intergenerationally irresponsible approach of not taking action deepens the generational divide and if not much gets done in the next 2-3 election cycles, then the income trajectory of the younger generations will be hampered by tax payments that will need to be increased, creating social tension between generations and hampering equity between Czechs now alive and their yet unborn compatriots.

\section{Acknowledgement}

This paper encourages subsequent research leading up to proposing guidelines towards a more intergenerationally just public finance management in an ageing small open economy as part of an effort during the doctoral studies of the author.

The author of the paper is thankful to doc. Ing. Petr Rozmahel, Ph.D. for valuable comments during the $2020 \mathrm{KPCBE}$ conference where the draft of the paper was presented, also to the organizers of the conference and to the anonymous reviewer for her much-appreciated critique.

\section{References}

[1] AUERBACH, A. J., J. GOKHALE and L. J. KOTLIKOFF, 1991. A Meaningful Alternative to Deficit Accounting (No. 3589). Working Paper.

[2] BONIN, H. and C. PATXOT, 2004. Generational accounting as a tool to assess fiscal sustainability: an overview of the methodology.

[3] BONIN, H., C. PATXOT and G. SOUTO, 2014. Cyclically-Neutral Generational Accounting. Fiscal Studies, 35(2), 117-137.

[4] BUCHANAN, J. M., 1958. Public principles of public debt. Homewood: Richard Irwin

[5] CHAMBER OF DEPUTIES PROCEEDINGS 812/3. Available at: https://www.psp.cz/sqw/text/tiskt.sqw? $\mathrm{O}=8 \& \mathrm{CT}=812 \& \mathrm{CT} 1=3$

[6] CHAMBER OF DEPUTIES PROCEEDINGS 812/4. Available at: https://www.psp.cz/sqw/text/tiskt.sqw? $\mathrm{O}=8 \& \mathrm{CT}=812 \& \mathrm{CT} 1=4$, 
[7] CZECH STATISTICAL OFFICE (CSO), 2017. Výsledky zdravotnických účtů ČR 2010-2015 (Revize). Available at: https://www.czso.cz/csu/czso/vysledkyzdravotnickych-uctu-cr-2010-2015-revize

[8] CSO, 2018. Projekce obyvatelstva České republiky 2018 -2100. Available at: https://www.czso.cz/csu/czso/projekce-obyvatelstva-ceske-republiky-2018-2100

[9] CSO, 2020a. Vybrané demografické údaje. Obyvatelstvo. Available at: https://www.czso.cz/documents/10180/123502877/32018120_0101.pdf/5da70908-dcde4110-8ab8-ffde779b9794? version=1.0

[10] CSO, 2020b. Databáze národních účtů. Národni úćty; pracovníci. Available at: http://apl.czso.cz/pl//rocenka/rocenka.indexnu

[11] ČSSZ, 2020. Průměrná výše solo důchodů v ČR. Available at: https://www.cssz.cz/documents/20143/99428/Prumerna_vyse_solo_duchodu_v_CR_v_c asove_rade.pdf/a9b4355f-343f-7f3c-eaef-485a15ec2098

[12] CZECH FISCAL COUNCIL, 2020. Report on the Long-Term Sustainability of Public Finances 2020. Available at: https://unrr.cz/wp-content/uploads/2020/09/REPORT-ONTHE-LONG-TERM-SUSTAINABILITY-OF-PUBLIC-FINANCES-2020.pdf

[13] EUROPEAN COMMISSION (EC), 2011. Council directive 2011/85/EU of 8th november 2011 on requirements for budgetary frameworks of the member states.

[14] EUROPEAN COMMISSION (EC), 2020. Medium-term Budgetary Objectives (MTOs). Available at: https://ec.europa.eu/info/business-economy-euro/economic-and-fiscalpolicy-coordination/eu-economic-governance-monitoring-prevention-correction/stabilityand-growth-pact/preventive-arm/medium-term-budgetary-objectives-mtos en accessed $\underline{20.9 .2020}$

[15] FIALA, T. a J. LANGHAMROVÁ, 2012. Možný vývoj úrovně vzdělání populace České republiky do roku 2050 aneb jak se bude vyvíjet lidský kapitál. Fórum sociálni politiky, 6(5), 2-8.

[16] GAGNÉ, A. et al., 2016. The index of intergenerational equity-2016. Available at. https://www.analysisgroup.com/uploadedfiles/content/insights/publishing/the_index_of_i ntergenerational_equity_2016.pdf

[17] JÍLKOVÁ, E. and V. ŘíHOVÁ, 2018. Change in the Quantity of Labour Force Caused by the Demographic Development in the Czech Republic, Ageing 2018: Proceedings of the $4^{\text {th }}$ Gerontological Interdisciplinary Conference (pp. 122-133 ). Prague, CZech Republic: Charles University, third Faculty of Medicine. Available at: http://www.konferencestarnuti.cz/files/Starnuti_2018_sbornik.pdf

[18] MINISTRY OF FINANCE ČR, 2020. Makroekonomická predikce - září 2020. Praha: Ministerstvo financí ČR.

[19] MINISTRY OF FINANCE ČR, 2017. Státní závěrečný účet ČR za rok 2015. Available at: https://www.mfcr.cz/cs/verejny-sektor/statni-rozpocet/plneni-statnihorozpoctu/2015/statni-zaverecny-ucet-za-rok-2015-26636

[20] MODIGLIANI, F., 1961. Long-run implications of alternative fiscal policies and the burden of the national debt. The Economic Journal, 71(284), 730-755.

[21] MUSGRAVE, R. A., 1988. Public debt and intergeneration equity. In The Economics of Public Debt (pp. 133-148). Palgrave Macmillan, London. 
[22] OECD, 2020. Přehledy důchodových systémů v zemích OECD: Česká Republika. Available at: http://duchodovakomise.cz/wp-content/uploads/2020/11/OECDPenzijn\%C3\%AD-p\%C5\%99ehled-\%C4\%8CR.pdf

[23] OECD, 2018. Education at a Glance 2018: OECD Indicators, OECD Publishing, Paris. Available at: https://doi.org/10.1787/eag-2018-en

[24] ROBINSON, M., 1998. Measuring compliance with the golden rule. Fiscal Studies, 19(4), 447-462.

[25] SENATE OF THE CZECH REPUBLIC PROCEEDINGS (SCR) - 17.4.2020. Available at: https://www.senat.cz/xqw/webdav/pssenat/original/94654/79382/86170

[26] U. N., 2016. Transforming our world: The 2030 agenda for sustainable development.

[27] Law no. 23/2017. Zákon č. 23/2017 Sb. o pravidlech rozpočtové odpovědnosti. Available at: https://www.zakonyprolidi.cz/cs/2017-23 